Article

\title{
Isolation, Identification and Biotechnological Applications of a Novel, Robust, Free-living Chlorococcum (Oophila) amblystomatis Strain Isolated from a Local Pond
}

\author{
Nádia Correia ${ }^{1,2}\left(\right.$, Hugo Pereira ${ }^{3}{ }^{\circledR}$, Joana T. Silva ${ }^{1}$, Tamára Santos ${ }^{3}$, Maria Soares ${ }^{1}$, \\ Carolina B. Sousa $^{3,4}$, Lisa M. Schüler ${ }^{3}$, Margarida Costa ${ }^{1} \mathbb{}$, João Varela ${ }^{3, *} \mathbb{C}$, Leonel Pereira ${ }^{2} \mathbb{C}$ \\ and Joana Silva ${ }^{1}$ \\ 1 Allmicroalgae Natural Products S.A., Research and Development Department-Rua 25 de Abril, $\mathrm{n}^{\circ}$ 19, \\ 2445-413 Pataias, Portugal; nadiasgcorreia@gmail.com (N.C.); joanatlfsilva@gmail.com (J.T.S.); \\ maria.soares@allmicroalgae.com (M.S.); costa.anamarg@gmail.com (M.C.); \\ joana.g.silva@allmicroalgae.com (J.S.) \\ 2 MARE-Marine and Environmental Sciences Centre, Department of Life Sciences, University of Coimbra, \\ 3000-456 Coimbra, Portugal; leonel.pereira@uc.pt \\ 3 CCMAR - Centre of Marine Sciences, University of Algarve, Gambelas, 8005-139 Faro, Portugal; \\ hgpereira@ualg.pt (H.P.); tfsantos@ualg.pt (T.S.); carolbrunos@yahoo.com (C.B.S.); \\ lmschueler@ualg.pt (L.M.S.) \\ 4 Global Health and Tropical Medicine (GHMT), Instituto de Higiene e Medicina Tropical, \\ Universidade Nova de Lisboa, 1349-008 Lisboa, Portugal \\ * Correspondence: jvarela@ualg.pt; Tel.: +351-289-800-900; Fax: +351-289-800-069
}

Received: 23 March 2020; Accepted: 23 April 2020; Published: 27 April 2020

\begin{abstract}
Bioprospection of novel autochthonous strains is key to the successful industrial-scale production of microalgal biomass. A novel Chlorococcum strain was recently isolated from a pond inside the industrial production facility of Allmicroalgae (Leiria, Portugal). Phylogenetic analysis based on $18 \mathrm{~S}$ ribosomal ribonucleic acid (rRNA) gene sequences suggests that this isolate is a novel, free-living Oophila amblystomatis strain. However, as our phylogenetic data strongly suggests that the aforementioned taxon belongs to the genus Chlorococcum, it is here proposed to rename this species as Chlorococcum amblystomatis. In order to characterize the biotechnological potential of this novel isolate, growth performance and biochemical composition were evaluated from the pilot $\left(2.5-\mathrm{m}^{3}\right)$ to industrial $\left(10-\mathrm{m}^{3}\right)$ scale. The highest maximum areal productivity $\left(36.56 \mathrm{~g} \cdot \mathrm{m}^{-2} \cdot\right.$ day $\left.^{-1}\right)$ was reached in a $10-\mathrm{m}^{3}$ tubular photobioreactor (PBR), as compared to that obtained in a $2.5-\mathrm{m}^{3}$ PBR $\left(26.75 \mathrm{~g} \cdot \mathrm{m}^{-2} \cdot \mathrm{day}^{-1}\right)$. Chlorococcum amblystomatis displayed high protein content $(48 \%-56 \%$ dry weight (DW)) and moderate levels of total lipids (18\%-31\% DW), carbohydrates $(6 \%-18 \% \mathrm{DW})$ and ashes $(9 \%-16 \%$ DW). Furthermore, the lipid profile was dominated by polyunsaturated fatty acids (PUFAs). The highest pigment contents were obtained in the 2.5- $\mathrm{m}^{3} \mathrm{PBR}$, where total chlorophylls accounted for $40.24 \mathrm{mg} \cdot \mathrm{g}^{-1} \mathrm{DW}$, followed by lutein with $5.37 \mathrm{mg} \cdot \mathrm{g}^{-1} \mathrm{DW}$. Overall, this free-living Chlorococcum amblystomatis strain shows great potential for nutritional applications, coupling a promising growth performance with a high protein content as well as relevant amounts of PUFAs, chlorophyll, and carotenoids.
\end{abstract}

Keywords: bioprospection; microalgae; Chlorococcum (Oophila) amblystomatis; photobioreactors; industrial-scale production; biotechnological applications 


\section{Introduction}

Microalgal biodiversity remains largely unexplored and bioprospection efforts may represent an opportunity to discover novel metabolites and promote biomass production at lower costs $[1,2]$. These microorganisms have been widely recognized as a cornerstone for bioeconomy and biorefinery development, due to their high applicability as feedstocks for food, feed, bioplastics, biofertilizers, and biofuels as well as for wastewater treatment and $\mathrm{CO}_{2}$ mitigation [3-5]. In Europe, macroand microalgae were recognized in the Strategic Energy Technological Plan (SET-PLAN) as a part of the key-value chain for advanced biomaterials production. Portugal, as a coastal country, has excellent climatic conditions and a great potential for a sustainable industrial microalgal cultivation [5]. Nevertheless, the high cost of microalgal production is still the main restriction associated with the commercialization of biomass for different commodities [5,6].

The world's increasing population and the predictions of an insufficient protein supply have led to research on new alternative and unconventional protein sources [7]. Algal biomass is currently considered as a good candidate for this purpose since these photosynthetic aquatic microorganisms are able to synthesize all the essential amino acids and their cultivation does not compete for arable land, as they can be grown in bioreactors [3,5]. Proteins are the main constituents of microalgae and one of the most important products of microalgae-based biorefineries [8]. Interestingly, these proteins, and peptides thereof, are very interesting for functional food applications due to their biological activities, in particular those related to the prevention and reduction of hypertension, oxidative stress, cancer, diabetes, inflammation, and immune disorders [9]. Moreover, as microalgae contain large amounts of pigments (e.g., carotenoids), many of them with known antioxidant properties and biomedically relevant bioactivities, microalgal biomass can be used to fortify or supplement food, feed, and cosmetics, improving their basic market value while providing increased health benefits [10]. This is in line with the expected increase in the worldwide market size of natural pigments fueled by a growing demand for such products by the consumers [3,5].

Bioprospecting for novel microalgal species and promoting industrial biomass production is key to improving the current portfolio of available strains for different biotechnological applications. The screening for molecules and activities of biotechnological interest as well as the understanding of microalgal ecosystem functioning are essential to develop sustainable and economical solutions for today's civilization and environmental needs [11-13].

The present work aimed to characterize and evaluate the biotechnological potential of a new isolate obtained from a pond at the Allmicroalgae facilities whose $18 \mathrm{~S}$ ribosomal deoxyribonucleic acid (rDNA) sequence is identical to that of Oophila amblystomatis. Interestingly, this sequence clusters together with those of the Stephanosphaerinia macroclade belonging to the genus Chlorococcum, suggesting that O. amblystomatis should be reclassified as Chlorococcum amblystomatis. As the biotechnological use of this novel isolate was the focus of the present work, its growth performance in the pilot and industrial-scale systems was assessed. In addition, its composition in terms of protein, lipids, carbohydrates, and pigments were evaluated to determine the nutritional potential of this microalga.

\section{Materials and Methods}

\subsection{Environmental Sampling and Strain Isolation}

The microalga used in this work, Chlorococcum amblystomatis, was obtained from a water sample collected from a freshwater pond in the production facility of Allmicroalgae, located in Pataias (Leiria, Portugal). The isolation process was taken according to Parvin et al. [14]. Briefly, to isolate novel microalgal strains, samples were centrifuged several times in order to separate microorganisms according to their density gradient. The cells were then successively diluted and streaked on plates containing growth medium (Sameca, Porto, Portugal) whose composition is based on Guillard's F/2. Different colonies were separated and observed microscopically. Streak-plating was performed in order to obtain unialgal, non-axenic, colonies. These isolated cultures were then stored in solid and 
liquid media on Allmicroalgae culture collection at $17^{\circ} \mathrm{C}$ and $12 \mathrm{~h}$ of light irradiance per day, under a continuous photon flux density of $20 \mu \mathrm{mol} \cdot \mathrm{m}^{-2} \cdot \mathrm{s}^{-1}$.

\subsection{Microscopic Observation and Molecular Identification}

Microscopic images were acquired in a Zeiss AXIO Scope A1 microscope with a Zeiss AXIOCAM 503 color camera and ZEN Blue 2.5 lite software (Carl Zeiss Microscopy GmbH, Jena, Germany), using the 40-x lens. Microscopy was carried out using differential interference contrast (DIC).

Phylogenetic analysis was performed through Maximum-likelihood and Bayesian inference using a partial sequence of C. amblystomatis 18S rRNA gene, which was deposited in GenBank with the accession number MT026583. The DNA sample was obtained, and its sequence was generated as described in Pereira et al. [15] using the 18SUnivFor and 18SUnivRev primers. The substitution models that best fit the data were selected using MrModeltest2 v.2.3 [16] and PAUP* v.4.0b10 [17] applying the Akaike information criteria (AIC; Akaike 1974). The maximum-likelihood analysis was performed using RaxML v.7.0.4 [18], assuming a GTR+G+I substitution model, with 400 bootstrap replicates. Posterior probabilities were determined by Markov Chain Monte Carlo (MCMC) sampling in MrBayes v.3.1.2 $[19,20]$. MrBayes analysis was also conducted using the model $G T R+G(n s t=6$ rates $=$ gamma) with six chains for 10,000,000 MCMC generations, sampling every 1000th generation and using the default for all the other settings. The MCMC runs convergence and burn-in were determined through the analysis of the generations vs log probability plot using the trace analysis tool TRACER v1.6 [21]. Using the burn-in, $20 \%$ of the trees were discarded.

ML best and consensus tree and BI consensus tree were generated using makeConsensusTree.py command and edited with the graphical viewer FigTree v.1.4.2 [22].

\subsection{Scale-Up and Biomass Production}

All experiments described were performed at Allmicroalgae industrial facilities between January and June 2018. A concentrated culture medium (Sameca, Porto, Portugal) based on Guillard's F/2 and supplemented with $25 \mu \mathrm{M}$ of iron (Hubel Olhão, Portugal) was added until a final concentration of $10 \mathrm{mM}$ of nitrate was reached.

Microalgal cultures were grown in the laboratory in 5-L bubble column reactors at $24 \pm 1{ }^{\circ} \mathrm{C}$ with continuously injected compressed $0.2-\mu \mathrm{m}$ filtered air, under a continuous photon flux density of $100 \mu \mathrm{mol} \cdot \mathrm{m}^{-2} \cdot \mathrm{s}^{-1}$. The $\mathrm{pH}$ of the culture medium was kept between 7.5 and 8.0 by periodical $\mathrm{CO}_{2}$ injection.

The scale-up to the outdoor pilot and industrial-scale reactors was performed by using five laboratory reactors to inoculate a $0.25-\mathrm{m}^{3}$ flat panel (FP) (Figure 1a). Cultures were aerated with $0.2-\mu \mathrm{m}$ filtered air, the $\mathrm{pH}$ was also maintained between 7.5 and 8.0 by $\mathrm{CO}_{2}$ pulse injection and the temperature inside the FP was maintained below $28^{\circ} \mathrm{C}$ by a sprinkler-like irrigation system. Thereafter, the $0.25-\mathrm{m}^{3}$ FP was used to inoculate a tubular photobioreactor (PBR) of $2.5-\mathrm{m}^{3}$ (Figure $1 \mathrm{~b}$ ) and about $80 \%$ of this was used as inoculum for a $10-\mathrm{m}^{3} \mathrm{PBR}$ (Figure 1c). The $\mathrm{pH}$ was maintained under 8.0 through an automated $\mathrm{CO}_{2}$ injection system and the temperature was kept under $28^{\circ} \mathrm{C}$ by a sprinkler-like irrigation system.

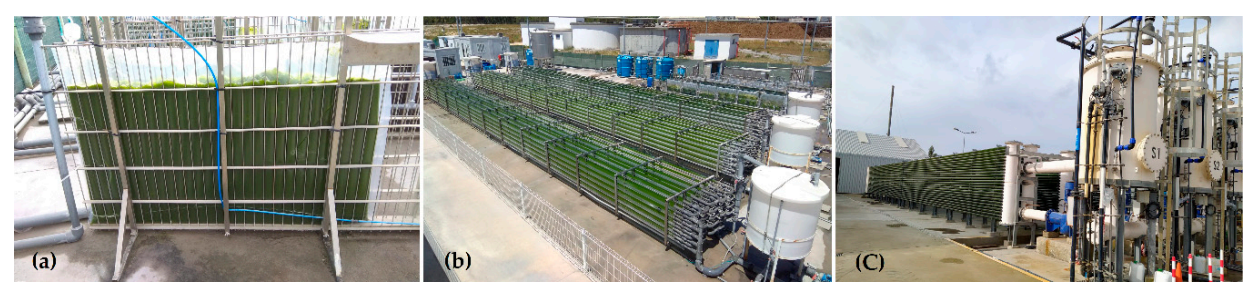

Figure 1. Different scale systems used for outdoor scale-up: (a) $0.25-\mathrm{m}^{3}$ flat panel photobioreactor (FP); (b) $2.5-\mathrm{m}^{3}$ pilot-scale tubular photobioreactor (PBR); (c) $10-\mathrm{m}^{3}$ industrial PBR. Pictures were provided by Allmicroalgae, Research and Development Department, Pataias, Portugal. 
For the assessment of growth performance and biomass production, three $0.25-\mathrm{m}^{3} \mathrm{FP}$ were cultivated between January and February at an average temperature of $13.6^{\circ} \mathrm{C}$ and light irradiance of $14.06 \mathrm{MJ} \cdot \mathrm{m}^{-2} \cdot$ day $^{-1}$. The $2.5-\mathrm{m}^{3}$ PBR triplicates were grown from March to May at an average temperature of $17.7^{\circ} \mathrm{C}$ and light irradiance of $19.04 \mathrm{MJ} \cdot \mathrm{m}^{-2} \cdot$ day $^{-1}$, while the industrial PBR of $10-\mathrm{m}^{3}$ triplicates were grown from May to June at an average temperature of $15.5^{\circ} \mathrm{C}$ and light irradiance of about $20.10 \mathrm{MJ} \cdot \mathrm{m}^{-2} \cdot \mathrm{day}^{-1}$.

\subsection{Growth Assessment}

Microalgal growth was monitored through biomass dry weight (DW). DW was determined by filtering a defined sample volume on micro-glass filters $(0.7 \mu \mathrm{m}, \mathrm{VWR})$, then washed with an equal volume of deionized water and dried using a moisture analyzer (KERN DBS, Balingen-Frommern, Germany) at $120^{\circ} \mathrm{C}$.

Volumetric biomass productivity $(P)$ was calculated as the difference in biomass concentration, in grams per liter $(X)$ during a specific period of time $(t)$, as shown by Equation (1) in which the indices 1 and 2 denote different time points:

$$
P\left(g \cdot L^{-1} \cdot \text { day }^{-1}\right)=\frac{X_{2}-X_{1}}{t_{2}-t_{1}}
$$

The areal biomass productivity $(\mathrm{Pa})$ was calculated as the product of the volumetric biomass productivity $(P)$ and the volume of the $\mathrm{PBR}$, in $\mathrm{L}(V)$ divided by the total ground area (including non-photic areas) of PBR, in square meters $(A)$ as shown in Equation (2):

$$
P_{a}\left(g \cdot m^{-2} \cdot d a y^{-1}\right)=P \times V / A
$$

The specific growth rate $(\mu)$ was determined by the quotient between the growth rate and the biomass concentration within a period of time, as seen in Equation (3):

$$
\mu\left(\operatorname{day}^{-1}\right)=\frac{\ln \left(X_{2} / X_{1}\right)}{t_{2}-t_{1}}
$$

where $X_{2}$ and $X_{1}$ refer to biomass concentration $\left(\mathrm{g} \cdot \mathrm{L}^{-1}\right)$ at different time points.

The photosynthetic efficiency was determined as the ratio between the higher heating value (HHV) and sun irradiation. Temperature and solar radiation were measured using a meteorological station (R.M. Young, Michigan, USA) and a pyranometer (Apogee UT SP-110, Logan, USA). The HHV was calculated as indicated in Equation (4) and as previously recommended by Callejón-Ferre et al. [23]:

$$
H H V\left(k J \cdot g^{-1}\right)=-3.393+0.507 . C-0.341 . H+0.067 . N
$$

Elemental analysis of $\mathrm{C}, \mathrm{H}$ and $\mathrm{N}$ were performed as described in Section 2.5.

\subsection{Biochemical Composition}

The biochemical composition was performed with biomass grown until the latest exponential phase, which was freeze dried prior to analysis. Elemental analysis of $\mathrm{C}, \mathrm{H}$ and $\mathrm{N}$ were performed using a Vario EL III (Vario EL, Elementar Analyser System, GmbH, Hanau, Germany) according to the manufacturer's procedure. Total proteins were calculated by multiplying the $N$ content given by elemental analysis with the standard conversion factor of 6.25 [24].

Total lipid content was determined following the Bligh \& Dyer [25] method with some modifications [15]. Briefly, biomass was extracted with a mixture of chloroform, methanol, and water (1:2:0.8, v:v:v) and homogenized with an IKA Ultra-Turrax disperser (IKA-Werke GmbH, Staufen, Germany) on ice for $60 \mathrm{~s}$. Centrifugation allowed phase separation and the organic phase was transferred to new vessels. Afterwards, a known volume $(0.7 \mathrm{~mL})$ was pipetted to pre-weighed tubes 
and evaporated at $60{ }^{\circ} \mathrm{C}$. The resulting dried residue was weighed and compared with the DW to provide an accurate determination of the lipid fraction.

The ash content was determined by the weight difference before and after the combustion of the biomass. Biomass was heated at $550{ }^{\circ} \mathrm{C}$ during $8 \mathrm{~h}$ using a furnace (J. P. Selecta, Sell horn R9-L, Barcelona, Spain).

Carbohydrates were calculated by the difference of the other macronutrients analyzed.

Fatty acids were converted into the corresponding fatty acid methyl esters (FAME) according to Lepage \& Roy [26] protocol, modified by Pereira et al. [15]. FAME were analyzed in a gas chromatography-mass spectrometry (GC-MS) analyzer (Bruker SCION 456/GC, SCION TQ MS) equipped with a ZB-5MS capillary column $(30 \mathrm{~m} \times 0.25 \mathrm{~mm}$ of internal diameter, $0.25 \mu \mathrm{m}$ of film thickens, Phenomenex), using helium as the carrier gas. The temperature program was $60^{\circ} \mathrm{C}$ for $1 \mathrm{~min}$, $30{ }^{\circ} \mathrm{C} \cdot \mathrm{min}^{-1}$ to $120^{\circ} \mathrm{C}, 5^{\circ} \mathrm{C} \cdot \mathrm{min}^{-1}$ to $250{ }^{\circ} \mathrm{C}$ and final increase of $20^{\circ} \mathrm{C} \cdot \mathrm{min}^{-1}$ to $300{ }^{\circ} \mathrm{C}$. Injection temperature was $300^{\circ} \mathrm{C}$. For identification and quantification of FAME, five different concentrations of the standards Supelco ${ }^{\circledR} 37$ component FAME Mix 41 (Sigma-Aldrich, Sintra, Portugal) were analyzed in order to establish calibration curves for each of the standard.

For pigments extraction, $10 \mathrm{mg}$ of fresh biomass was extracted with glass beads in $6 \mathrm{~mL}$ of acetone for $10 \mathrm{~min}$. The sample was centrifuged (HERMLE Z300, New York, NY, USA) at $3500 \mathrm{rpm}$ for 10 min until complete loss of the pellet color. The supernatant was analyzed using a spectrophotometer (Genesys 10S UV-VIS, MA, USA) in the scanning spectrum (380 to $700 \mathrm{~nm}$ ) and the data were analyzed by the Excel Add-In Solver on Windows 2013.

Carotenoid profiles were determined according to Couso et al. [27]. Briefly, the extract was completely dried under nitrogen flow, resuspended in high-performance liquid chromatography (HPLC)-grade methanol and filtered $(0.22 \mu \mathrm{m})$ into an amber HPLC vial. The separation and chromatographic analysis of pigments were performed by Merck Hitachi LaCrom Elite HPLC (Darmstadt, Germany) equipped with a diode-array detector, using a LiChroCART RP-18 (5 $\mu \mathrm{m}$, $250 \times 4 \mathrm{~mm}$, LiChrospher) column and a flow rate of $1 \mathrm{~mL} \cdot \mathrm{min}^{-1}$. The mobile phase consisted of ethyl acetate as solvent $\mathrm{A}$ and 9:1 (v:v) acetonitrile:water as solvent $\mathrm{B}$. The gradient program applied was: 0-16 min, $0 \%-60 \%$ A; $16-30 \mathrm{~min}, 60 \%$ A; 30-32 $\mathrm{min}, 100 \%$ A and $30-35 \mathrm{~min} 100 \%$ B. The injection volume was $100 \mu \mathrm{L}$. Quantification of pigments was carried out at $450 \mathrm{~nm}$ using calibration curves of the pigment standards neoxanthin, violaxanthin, lutein and $\beta$-carotene. The HPLC chromatogram with carotenoids retention times (Figure S1) and respective calibration curves of pigment standards (Figures S2-S5) is given in Supplementary Materials.

\subsection{Statistical Analysis}

Statistical analyses were performed using $R$ software (version 3.6.1) through RStudio IDE (version 1.2.1335). When three or more conditions were analyzed, ANOVA was performed with the multiple comparisons of Tukey-HSD. For the comparison of groups of independent results, a $t$-student test was used. A confidence level $\geq 95 \%$ was set. For each test, the mean and standard deviation were determined among biological triplicates.

\section{Results and Discussion}

\subsection{Morphological Characterization}

The microalgal specimen collected in the freshwater pond at the facilities of Allmicroalgae was identified based on botanical, micro-morphological features and taxonomy as Chlorococcum Meneghini. A voucher was deposited in the Allmicroalgae culture collection with number $0030 \mathrm{CN}$.

Vegetative cells of the symbiotic algae appeared grass-green, live as solitary cells or in temporary groups of indefinite form without a mucilaginous envelope, are ellipsoidal to spherical and vary in size from 8 to $25 \mu \mathrm{m}$. Reproduction within the genus Chlorococcum is mainly asexual, by biflagellate zoospores (or aplanospores in case of water stress) that do not become spherical upon cessation 
of motility but retain an ovoid, ellipsoid shape for some days [28,29]. By light microscopy, in three-week-old liquid cultures, green vegetative cells with a hollow, parietal chloroplast with or without an open surface were observed. In the basal part of the chloroplast, a spherical pyrenoid was present and the nucleus was in a central position in the cell (Figure 2a). Temporary groups of cells of indefinite form and without a mucilaginous envelope (Figure 2c) were seen. In three-day-old liquid cultures, numerous zoosporangia (Figure $2 \mathrm{~d}-\mathrm{f}$ ), zoospores (Figure $2 \mathrm{~b}$ ) and young green vegetative cells became evident. Zoospores had two flagella, an anterior stigma, one spherical pyrenoid in the central region and a nucleus posterior to pyrenoid. Zoospores had an ellipsoidal form ( $3.59 \pm 0.43 \mu \mathrm{m}$ wide and $8.56 \pm 0.82 \mu \mathrm{m}$ long), young green cells had an ellipsoidal to ovoid form $(6.70 \pm 1.23 \mu \mathrm{m}$ wide and $9.66 \pm 1.23 \mu \mathrm{m}$ long) and mature green cells were spherical $(15.14 \pm 2.34 \mu \mathrm{m})$. Prolonged observations of cultures show that this Chlorococcum multiplication seems to be similar to Chlorococcum infusionum Meneghini, mainly through the endogenous division of the content of the vegetative cell by progressive cleavage of a mother protoplast into uninucleate segments [30]. The number of zoospores might vary according to the size of the mother cell. Once completely formed, zoospores free themselves by bursting the zoosporangium membrane (Figure 2e) due to excess pressure inside.
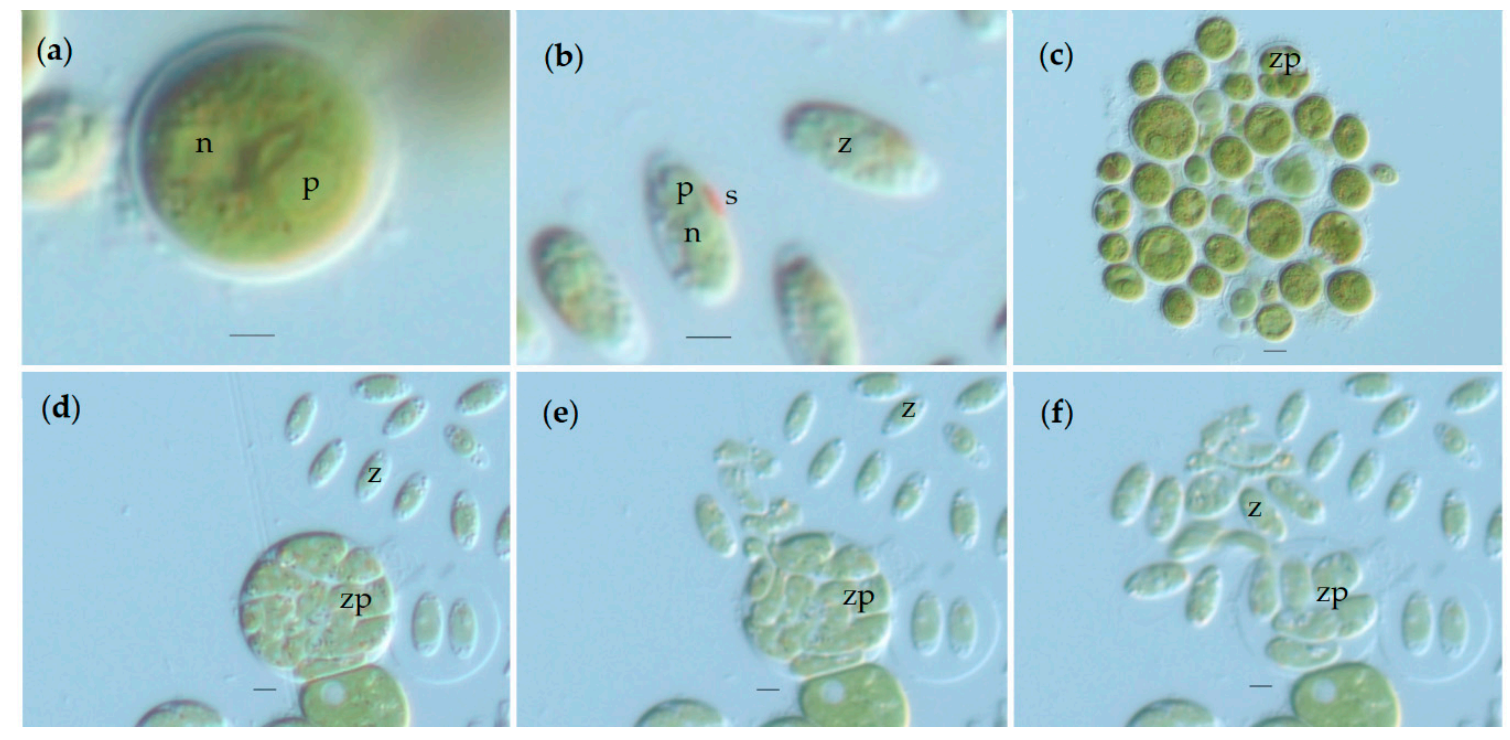

Figure 2. Microscopic images of Chlorococcum amblystomatis life stages using the differential interference contrast (DIC): (a) vegetative cell; (b) zoospore; (c) group of cells with indefinite form; (d) zoosporangium; (e) and (f) burst of zoosporangium membrane and realizing of zoospores. $\mathrm{n}=$ nucleus, $\mathrm{p}=$ pyrenoid, $\mathrm{s}=$ stigma, $\mathrm{z}=$ zoospore, $\mathrm{zp}=$ zoosporangium. Scale bar $(\mathbf{a})$ and $(\mathbf{b})=2 \mu \mathrm{m},(\mathbf{c})$ to $(\mathbf{f})=5 \mu \mathrm{m}$.

\subsection{Molecular Identification and Phylogenetic Analysis}

For the determination of the taxonomic classification of the new isolate within the Chlorococcaceae, the family to which the genus Chlorococcum belongs, molecular phylogenetic analysis was carried out. Sequences of $18 \mathrm{~S}$ rRNA genes from several Chlorococcaceae microalgae were analyzed using Bayesian (BI) and Maximum Likelihood (ML) inference. Chlorella vulgaris 18S rRNA gene was used as an outgroup. BI and ML trees topology (Figure 3) indicates that the strain isolated from a pond located at Allmicroalgae industrial facilities (accession number: MT026583) belongs to a taxonomic unit sister to C. minutum/C. aquaticum, with an almost maximum posterior probability (0.99) and a 93\% ML bootstrap value. Interestingly, C. ellipsoideum appears to be an outgroup, branching off these taxa with maximum support. Although this isolate does present similarities to $C$. infusionum, the holotype of the genus, concerning its reproduction, phylogenetic analysis strongly suggests that belongs to the Stephanosphaerinia macroclade, rather than to the Moewusinia, the macroclade of C. infusionum (Figure 3) [31]. Moreover, upon submitting our sequence to GenBank, the authors found that this 
sequence is $100 \%$ identical to an Oophila amblystomatis (Kingston isolate, Oophila clade A) sequence with the accession number KY091671 [32] and to other sequences that have not been classified down to the species level. This finding is quite interesting, as the phylogenetic data here presented strongly indicates that $O$. amblystomatis does belong to the genus Chlorococcum. This species is often isolated as a symbiont in eggs of several amphibian species, but its proper taxonomy has remained uncertain [32]. Recently, it has been reported that this species can also occur as free-living microalgae [33]. Taken together, it is here proposed to rename O. amblystomatis as Chlorococcum amblystomatis. This proposal is supported not only by the results of Figure 3, but also by the latest attempt at defining the taxonomy of this species [32]. Indeed, these authors hint that that sequences of the Oophila clade A symbionts cluster with those of Chlorococcum, unlike "Oophila" clade B isolates, which appear to be closely related to taxa classified as Chlamydomonas [32].

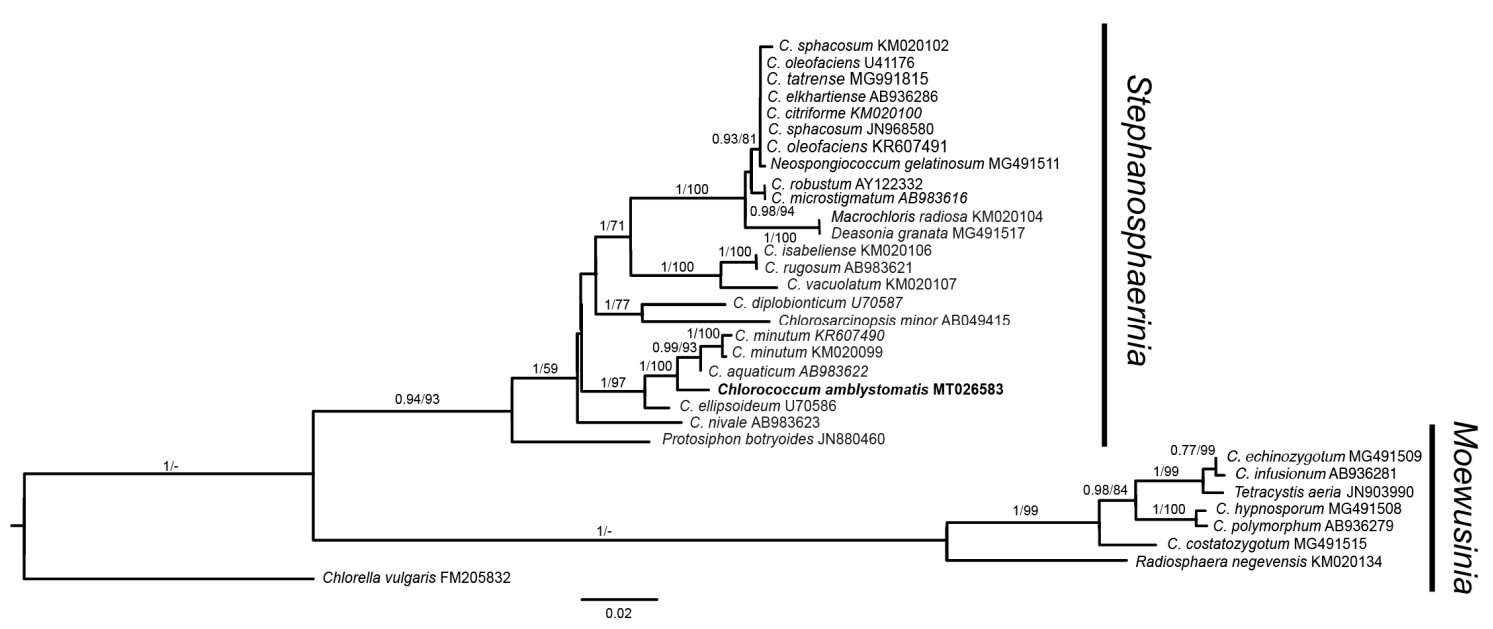

Figure 3. Bayesian inference trees of the family Chlorococcaceae using $18 \mathrm{~S}$ ribosomal ribonucleic acid (rRNA) sequences show that the novel isolate (acc. number: MT026583) forms a clade sister to C. minutum/C. aquaticum with C. ellipsoideum as an outgroup. Interestingly, the MT026583 sequence is identical to that of Oophila amblystomatis, a species that can be either free-living [33] or a salamander egg symbiont [32]. As these results strongly suggest that O. amblystomatis belongs to the genus Chlorococcum, it is here proposed that this species should be renamed as Chlorococcum amblystomatis as given in the tree. Moreover, these results confirm previous data suggesting that the genus Chlorococcum can be clearly divided into two macroclades: Stephanosphaerinia and Moewusinia [31]. ML bootstrap values $(>50)$ and BI posterior probabilities $(>0.70)$ are indicated at the respective branches. The accession number of each sequence used is given after the taxonomic classification of each leaf node.

\subsection{Scale-Up and Biomass Production}

Growth assays were performed in PBRs of different volumes and geometry, namely, pilot-scale $0.25-\mathrm{m}^{3} \mathrm{FP}, 2.5-\mathrm{m}^{3}$ tubular PBR and industrial-scale $10-\mathrm{m}^{3}$ tubular PBR. The biomass productivities, specific growth rates and photosynthetic efficiencies of $C$. amblystomatis are presented in Table 1 . The higher volumetric productivities were achieved in the pilot-scale systems, reaching similar global and maximum productivities $(p \geq 0.05)$ in the $0.25-\mathrm{m}^{3} \mathrm{FP}\left(0.07\right.$ and $\left.0.27 \mathrm{~g} \cdot \mathrm{L}^{-1} \cdot \mathrm{day}^{-1}\right)$ and $2.5-\mathrm{m}^{3} \mathrm{PBR}$ $\left(0.09\right.$ and $\left.0.26 \mathrm{~g} \cdot \mathrm{L}^{-1} \cdot \mathrm{day}^{-1}\right)$. On the other hand, compared to pilot-scale systems, the industrial scale $10-\mathrm{m}^{3}$ PBR registered significantly lower global and maximum volumetric productivities of 0.05 and $0.09 \mathrm{~g} \cdot \mathrm{L}^{-1} \cdot$ day $^{-1}$, respectively $(p<0.05)$. The obtained volumetric productivities are lower than those previously reported by Cabanelas et al. [34] for Alkivia (Chlorococcum) littorale grown in a horizontal tubular PBR of $0.09-\mathrm{m}^{3}\left(0.74 \mathrm{~g} \cdot \mathrm{L}^{-1} \cdot\right.$ day $^{-1}$ in Oslo, $0.7 \mathrm{~g} \cdot \mathrm{L}^{-1} \cdot$ day $^{-1}$ in Wageningen, $0.58 \mathrm{~g} \cdot \mathrm{L}^{-1} \cdot \mathrm{day}^{-1}$ in Rio de Janeiro and $0.6 \mathrm{~g} \cdot \mathrm{L}^{-1} \cdot \mathrm{day}^{-1}$ in Cadiz). 
Table 1. Maximum volumetric productivity, overall volumetric productivity, maximum areal productivity and overall areal productivity, specific growth rate $(\mu)$ and photosynthetic efficiency (PE) of pilot- and industrial-scale tubular photobioreactors (PBR). Different letters indicate significant differences between reactors. Values are given as means \pm standard deviation $(n=3)$.

\begin{tabular}{|c|c|c|c|c|c|c|}
\hline \multirow{2}{*}{ Reactor } & \multicolumn{2}{|c|}{$\begin{array}{c}\text { Volumetric Productivity } \\
\left(\mathrm{g} \cdot \mathrm{L}^{-1} \cdot \mathrm{d}^{-1}\right)\end{array}$} & \multicolumn{2}{|c|}{$\begin{array}{c}\text { Areal Productivity } \\
\left(\mathrm{g} \cdot \mathrm{m}^{-2} \cdot \mathrm{d}^{-1}\right)\end{array}$} & \multirow[t]{2}{*}{$\underset{\left(d^{-1}\right)}{\mu}$} & \multirow[t]{2}{*}{$\begin{array}{l}\text { PE } \\
(\%)\end{array}$} \\
\hline & Maximum & Global & Maximum & Global & & \\
\hline $0.25-\mathrm{m}^{3} \mathrm{FP}$ & $0.27 \pm 0.02^{\mathrm{a}}$ & $0.07 \pm 0.00^{a, b}$ & $22.31 \pm 1.50^{\mathrm{a}}$ & $5.94 \pm 0.41^{a}$ & $0.16 \pm 0.00^{\mathrm{a}}$ & $0.73 \pm 0.02^{a}$ \\
\hline 2.5- $\mathrm{m}^{3}$ PBR & $0.26 \pm 0.02^{\mathrm{a}}$ & $0.09 \pm 0.02^{\mathrm{a}}$ & $26.75 \pm 2.47^{\mathrm{a}}$ & $8.65 \pm 1.62^{a, b}$ & $0.13 \pm 0.03^{a}$ & $1.33 \pm 0.12^{b}$ \\
\hline $10-\mathrm{m}^{3} \mathrm{PBR}$ & $0.09 \pm 0.03^{b}$ & $0.05 \pm 0.01^{b}$ & $36.56 \pm 1.52^{b}$ & $14.84 \pm 3.98^{b}$ & $0.16 \pm 0.02^{\mathrm{a}}$ & $1.84 \pm 0.18^{c}$ \\
\hline
\end{tabular}

However, an opposite trend was found for the areal productivity, where the highest maximum productivity was achieved in the $10-\mathrm{m}^{3}$ PBR, reaching $36.56 \mathrm{~g} \cdot \mathrm{m}^{-2} \cdot$ day $^{-1}(p<0.05)$. The overall areal productivity was also higher in the 10- $\mathrm{m}^{3}$ PBR, when compared to the FP $(p<0.05)$, but without significant differences when compared to the $2.5-\mathrm{m}^{3} \mathrm{PBR}(p \geq 0.05)$. C. amblystomatis has shown higher areal productivities in comparison with the same work of Cabanelas et al. [34] $\left(16.6 \mathrm{~g} \cdot \mathrm{m}^{-2} \cdot\right.$ day $^{-1}$ in Oslo, $15.7 \mathrm{~g} \cdot \mathrm{m}^{-2} \cdot$ day $^{-1}$ in Wageningen, $13.05 \mathrm{~g} \cdot \mathrm{m}^{-2} \cdot$ day $^{-1}$ in Rio de Janeiro and $13.5 \mathrm{~g} \cdot \mathrm{m}^{-2} \cdot$ day $^{-1}$ in Cadiz).

The explanation for the difference between volumetric and areal productivities among systems is due to the geometry of the reactors. As industrial PBRs have a high density of horizontal tubes, the lower tubes receive a lower amount of light irradiance, caused by shadowing, which reduces the volumetric production. Despite this, as the volume of biomass produced in the same area is substantially higher, it results in higher areal productivities. This trend was previously reported for the same PBRs geometry upon the cultivation of Tetraselmis sp. (Chlorophyta) CTP4 [12] and Phaeodactylum tricornutum (Bacillariophyta) [35].

Specific growth rates were similar among the different reactors $(p \geq 0.05)$ and considerably lower compared to that of $A$. littorale grown in a $0.09-\mathrm{m}^{3}$ PBR (from 0.46 day $^{-1}$ to 0.62 day $^{-1}$ ) [34]. In addition, the pilot-scale FP registered the lowest photosynthetic efficiency, $0.73 \%(p<0.05)$, while the industrial PBR achieved the highest value, $1.84 \%(p<0.05)$. Similar PEs were reported for P. tricornutum using the same $2.5-\mathrm{m}^{3}$ PBR $(1.11 \%)$ and $10-\mathrm{m}^{3}$ PBR $(2.08 \%)$ [35]. Favorable climacteric conditions and sunlight exposure during the growth period in the industrial PBR were beneficial to the culture growth. Higher photosynthetic efficiency was already expected in the industrial PBR, since the volume of culture per unit of area of the photic area is substantially higher. Furthermore, the FP aeration system is less efficient in comparison to that of the industrial PBR, hampering light absorption due to biofilm formation on the walls of the reactor.

\subsection{Biochemical Composition}

In order to further characterize C. amblystomatis, the biochemical composition of the biomass was analyzed. For this purpose, only biomass produced in the 2.5- and 10- $\mathrm{m}^{3}$ PBR was analyzed, since these are the culture systems used to produce biomass by Allmicroalgae in the large-scale industrial facility.

\subsubsection{Proximate Composition}

The content of proteins, lipids, carbohydrates, and ashes detected in the biomass produced in both PBRs is presented in Table 2.

The results obtained revealed that proteins are the main macronutrient present in C. amblystomatis biomass. The highest protein content was achieved in microalgal cells grown in the $2.5-\mathrm{m}^{3} \mathrm{PBR}$, reaching more than $55 \%$ of their DW $(p<0.05)$, while the biomass produced in the $10-\mathrm{m}^{3}$ PBR registered a protein content of $48 \%$ DW. Microalgal proteins are appreciated as an additive to feed for a wide variety of animals ranging from fish (aquaculture) to pets and farm animals and are very interesting for functional food applications due to their demonstrated biological activities impacting different 
human health conditions [3,9]. The lower value of protein ratio obtained in the biomass grown in the 10- $\mathrm{m}^{3}$ PBR was probably due to exposure of the cultures to stressful conditions. Even though the accumulation of carbohydrates in microalgae is mainly due to the net balance between photosynthesis and respiration [36], it would be expected that the biomass grown in the 10- $\mathrm{m}^{3}$ PBR showed the highest value of carbohydrates, since it was exposed to higher light irradiance. However, it was in the biomass grown in the pilot-scale PBR that the highest percentage of carbohydrates was detected, achieving $17.43 \%$ of biomass DW $(p<0.05)$, within the range of reported values for the majority of microalgae [4,9]. Indeed, under unfavorable conditions (e.g., high irradiance and nitrogen limitation), the excess of carbon fixed during photosynthesis may have been diverted into storage compounds such as lipids or carbohydrates $[4,9,37,38]$. This could also explain the higher lipid content observed in the biomass grown in the $10-\mathrm{m}^{3} \mathrm{PBR}(p<0.05), 31.44 \% \mathrm{DW}$, in comparison to that of microalgal cells grown in the $2.5-\mathrm{m}^{3} \mathrm{PBR}(18.33 \%)$.

Table 2. Biochemical composition of Chlorococcum amblystomatis biomass grown in the 2.5- and $10-\mathrm{m}^{3}$ tubular photobioreactors (PBR). Proteins, lipids, and carbohydrates are presented as the percentage of biomass dry weight (DW). Different letters indicate significant differences between reactors. Values are given as means \pm standard deviation $(n=3)$.

\begin{tabular}{ccccc}
\hline Reactor & Proteins (\%) & Lipids (\%) & Carbohydrates (\%) & Ashes (\%) \\
\hline $2.5-\mathrm{m}^{3}$ PBR & $55.72 \pm 2.85^{\mathrm{a}}$ & $18.33 \pm 0.97^{\mathrm{b}}$ & $17.43 \pm 3.58^{\mathrm{a}}$ & $9.88 \pm 5.87^{\mathrm{a}}$ \\
$10-\mathrm{m}^{3}$ PBR & $48.22 \pm 0.43^{\mathrm{b}}$ & $31.44 \pm 4.10^{\mathrm{a}}$ & $5.78 \pm 3.99^{\mathrm{b}}$ & $15.85 \pm 5.00^{\mathrm{a}}$ \\
\hline
\end{tabular}

\subsubsection{Fatty Acid Profile}

In order to assess the lipid composition of the biomass, the fatty acid profile was analyzed (Table 3). The FAME profile of $C$. amblystomatis is dominated by C16:4n-3 (21.94\%-23.65\% of total fatty acids; TFA), C16:0 (15.24\%-19.29\% of TFA), C18:4n-3 (8.61\%-8.83\% of TFA), C18:3n-3 (27.58\%-31.40\% of TFA) and C18:1 (5.34\%-6.27\% of TFA). Interestingly, this microalga contains a high content of polyunsaturated fatty acids (PUFAs), reaching $74.70 \%$ of TFA in the biomass produced in the $2.5-\mathrm{m}^{3}$ PBR, which is significantly higher than the $67.10 \%$ of TFA detected in the biomass obtained from the $10-\mathrm{m}^{3}$ PBR $(p<0.05)$. Saturated fatty acids (SFAs) and monounsaturated fatty acids (MUFAs) are similar between the reactors.

Overall, the FAME profile does not match with previous values reported for other Chlorococcum microalgae, wherein the FAME profile combines higher percentages of SFAs and MUFAs, and lower contents of PUFAs $[39,40]$, reinforcing the conclusion that $C$. amblystomatis is a species distinct from those whose fatty acid profiles have been described previously.

PUFAs are classified as $n-3$ and $n-6$ and play an important role in human and animal nutrition [41,42]. It is reported that $n-3$ fatty acids play an important role in the prevention of coronary heart disease and inflammatory disease, brain disorder, such as Alzheimer's disease and help in cancer therapy [43-45], while $n-6$ fatty acids are pro-inflammatory $[41,46]$. The functional sources of $n-3$ in microalgae are normally eicosapentaenoic (EPA, C20:5n-3) and docosahexaenoic (DHA, C22:6n-3) acids; however, chlorophytes and particularly freshwater microalgae are, in general, deficient in both C20 and C22 PUFAs [4,45]. Nevertheless, there are other important PUFAs such as linoleic (LA, C18:2n-6), $\alpha$-linolenic (ALA, C18:3n-3) and $\gamma$-linolenic (GLA, C18:3n-6) acids with proven biomedical and nutraceutical applications [42]. Furthermore, once consumed, these fatty acids are metabolized within mammalian cells. Thereby, ALA is converted to stearidonic (C18:4n-3) and eicosatetraenoic (C20:4n-3) acids to form EPA, which is further metabolized to DHA (C22:6n-3) [41,47]. Although the $n-3$ and $n-6$ PUFAs biosynthetic pathways share the same series of enzymes, the health effects are dependent on the $\Sigma n-6 / \Sigma n-3$ ratio [41,46,47], which is recommended to be lower than 10 by the World Health Organization (WHO) in order to prevent inflammatory, cardiovascular and nervous system disorders [46,47]. Therefore, since $C$. amblystomatis, presents a PUFA/SFA ratio of 4.30-2.81 and a $\Sigma n-6 / \Sigma n-3$ ratio of $0.10-0.13$, this strain can be considered as a good alternative source of dietary PUFA. 
Table 3. Fatty acid methyl esters (FAME) profile of Chlorococcum amblystomatis biomass grown in 2.5and $10-\mathrm{m}^{3}$ tubular photobioreactors (PBR). Different letters indicate significant differences between reactors. Values are given as means \pm standard deviation $(n=3)$.

\begin{tabular}{ccc}
\hline FAME $\%$ & $\mathbf{2 . 5}-\mathbf{m}^{\mathbf{3}} \mathbf{P B R}$ & $\mathbf{1 0}^{\mathbf{3}} \mathbf{P B R}^{\mathbf{P B}}$ \\
\hline C14:0 $16: 4 n-3$ & $0.76 \pm 0.09^{\mathrm{a}}$ & $2.88 \pm 0.87^{\mathrm{b}}$ \\
$\mathrm{C} 16: 3 n-3$ & $23.65 \pm 2.20^{\mathrm{a}}$ & $21.94 \pm 1.87^{\mathrm{a}}$ \\
$\mathrm{C} 16: 2 n-6$ & $4.15 \pm 0.40^{\mathrm{a}}$ & $2.75 \pm 0.47^{\mathrm{b}}$ \\
$\mathrm{C} 16: 1$ & $0.73 \pm 0.08^{\mathrm{a}}$ & $0.90 \pm 0.04^{\mathrm{a}}$ \\
$\mathrm{C} 16: 0$ & $2.59 \pm 0.23^{\mathrm{a}}$ & $2.70 \pm 0.59^{\mathrm{a}}$ \\
$\mathrm{C} 18: 4 n-3$ & $15.24 \pm 1.60^{\mathrm{a}}$ & $19.29 \pm 0.73^{\mathrm{b}}$ \\
$\mathrm{C} 18: 3 n-3$ & $8.61 \pm 1.15^{\mathrm{a}}$ & $8.83 \pm 2.43^{\mathrm{a}}$ \\
$\mathrm{C} 18: 3 n-6$ & $31.40 \pm 2.80^{\mathrm{a}}$ & $27.58 \pm 1.18^{\mathrm{a}}$ \\
$\mathrm{C} 18: 2 n-6$ & $3.22 \pm 1.26^{\mathrm{a}}$ & $3.21 \pm 0.69^{\mathrm{a}}$ \\
$\mathrm{C} 18: 1$ & $2.94 \pm 0.78^{\mathrm{a}}$ & $3.75 \pm 0.53^{\mathrm{a}}$ \\
$\mathrm{C} 18: 0$ & $5.34 \pm 0.34^{\mathrm{a}}$ & $6.27 \pm 0.76^{\mathrm{a}}$ \\
$\Sigma$ SFA & $1.37 \pm 0.56^{\mathrm{a}}$ & $2.71 \pm 1.06^{\mathrm{a}}$ \\
$\Sigma \mathrm{MUFA}$ & $17.37 \pm 2.42^{\mathrm{a}}$ & $23.92 \pm 3.54^{\mathrm{a}}$ \\
$\Sigma \mathrm{PUFA}$ & $7.93 \pm 0.04^{\mathrm{a}}$ & $8.97 \pm 1.35^{\mathrm{a}}$ \\
$\Sigma n-3$ & $74.70 \pm 2.46^{\mathrm{a}}$ & $67.10 \pm 3.30^{\mathrm{b}}$ \\
$\Sigma n-6$ & 67.81 & 61.10 \\
$\Sigma n-6 / \sum n-3$ & 6.89 & 7.86 \\
PUFA/SFA & 0.10 & 0.13 \\
\hline
\end{tabular}

\subsubsection{Pigment Composition}

The content of chlorophyll $a$ and $b$ and main carotenoid content were analyzed by spectrophotometry and the results are shown in Table 4.

Table 4. Pigment profile of Chlorococcum amblystomatis biomass grown in 2.5- and $10-\mathrm{m}^{3}$ tubular photobioreactors (PBR). Different letters indicate significant differences between reactors. Values are given as means \pm standard deviation $(n=3)$.

\begin{tabular}{ccc}
\hline Pigments (mg. $\mathbf{g}^{\mathbf{- 1}}$ ) & $\mathbf{2 . 5}^{\mathbf{3}} \mathbf{\text { PBR }}$ & $\mathbf{1 0}^{\mathbf{3}} \mathbf{\text { PBR }}$ \\
\hline Neoxanthin & $0.63 \pm 0.19^{\mathrm{a}}$ & $0.14 \pm 0.01^{\mathrm{b}}$ \\
Violaxanthin & $0.33 \pm 0.07^{\mathrm{a}}$ & $0.13 \pm 0.01^{\mathrm{b}}$ \\
Lutein & $5.37 \pm 0.78^{\mathrm{a}}$ & $2.49 \pm 0.09^{\mathrm{b}}$ \\
$\beta$-carotene & $1.25 \pm 0.14^{\mathrm{a}}$ & $0.64 \pm 0.03^{\mathrm{b}}$ \\
Chlorophyll $a$ and $b$ & $40.24 \pm 7.94^{\mathrm{a}}$ & $19.56 \pm 6.84^{\mathrm{b}}$ \\
\hline
\end{tabular}

The highest pigment content detected in C. amblystomatis was achieved in the pilot-scale $2.5-\mathrm{m}^{3}$ PBR $(p<0.05)$, with chlorophylls reaching $40.24 \mathrm{mg} \cdot \mathrm{g}^{-1}$, followed by lutein $\left(5.37 \mathrm{mg} \cdot \mathrm{g}^{-1}\right), \beta$-carotene $\left(1.25 \mathrm{mg} \cdot \mathrm{g}^{-1}\right)$, neoxanthin $\left(0.63 \mathrm{mg} \cdot \mathrm{g}^{-1}\right)$ and violaxanthin $\left(0.33 \mathrm{mg} \cdot \mathrm{g}^{-1}\right)$. Unfavorable growth conditions (e.g., pH fluctuation) can negatively affect pigment accumulation [48]. This could explain the lower contents registered in the biomass grown in the industrial PBR.

Photosynthetic microalgae contain chlorophyll ranges between 5 and $15 \mathrm{mg} \cdot \mathrm{g}^{-1}$ of DW $[3,10]$; contents as high as $40 \mathrm{mg} \cdot \mathrm{g}^{-1}$ have been reported for cultures grown under optimal conditions [45]. Interestingly, the chlorophyll content of $C$. amblystomatis was considerably higher $\left(>40 \mathrm{mg} \cdot \mathrm{g}^{-1}\right)$ without optimized growth conditions. Chlorophyll, due to its strong green color, is used as a natural dye in food formulation [45]. Besides, recent studies showed that chlorophyll consumption might lead to a decreased risk of colorectal cancer [10,49].

Lutein content is similar to the values previously reported for other microalgae that are known lutein-producers, such as Scenedesmus almeriensis (Chlorophyta) $\left(5.5 \mathrm{mg} \cdot \mathrm{g}^{-1}\right.$ at laboratory-scale, $4.5 \mathrm{mg} \cdot \mathrm{g}^{-1}$ at $\left.4-\mathrm{m}^{3} \mathrm{PBR}\right)$, Muriellopsis sp. (Chlorophyta) $\left(5.5 \mathrm{mg} \cdot \mathrm{g}^{-1}\right.$ at laboratory-scale, $4.3 \mathrm{mg} \cdot \mathrm{g}^{-1}$ 
at $\left.0.055-\mathrm{m}^{3} \mathrm{PBR}\right)$ and Chlorococcum citriforme $\left(7.2 \mathrm{mg} \cdot \mathrm{g}^{-1}\right.$ at laboratory-scale) [50]. Therefore, C. amblystomatis could be a promising lutein source, since the biomass produced in the $2.5-\mathrm{m}^{3}$ PBR reached significantly high contents $\left(>5 \mathrm{mg} \cdot \mathrm{g}^{-1}\right)$. Lutein is largely consumed as a feed additive in aquaculture and as a food colorant. Despite this, as it is an essential component for the macula lutea in the eye retina and lens, and since lutein from microalgae (E161g) was approved as a color additive in the EU and USA, another feasible application might be within the realm of the pharmaceutical industry $[10,44,50]$. In the eastern world, the percentage of people with Age-Related Macular Degeneration (ADM) disease is high and the recommended intake of lutein is $6 \mathrm{mg}$ daily, which might often be achieved via ingestion of food supplements [44,50].

$\beta$-carotene is the second most abundant carotenoid in C. amblystomatis biomass; however, its contents are lower in comparison with the main natural producer of this carotenoid, Dunaliella salina (Chlorophyta) (11-21 $\mathrm{mg}^{-\mathrm{g}^{-1}}$ [51]. This pigment holds an important nutritional use due to its ability to act as provitamin A, increasing the vitamin A production in the organism [44]. The great demand of $\beta$-carotene by the food, pharmaceutical, and cosmetic industries has mainly been met by production by chemical synthesis; however, the demand for natural sources is increasing, holding an estimated market size of 10 to 100 tons per year and a market value of $>750 € \cdot \mathrm{kg}^{-1}$ [3].

In addition, Chlorococcum microalgae have been reported to be capable of producing about $18 \mathrm{mg} \cdot \mathrm{L}^{-1}$ of astaxanthin and about $45 \mathrm{mg} \cdot \mathrm{L}^{-1}$ of total secondary carotenoids, upon the induction of the biosynthesis and accumulation of these pigments. Haematococcus (Chlorophyta), the main astaxanthin-producer $\left(15-30 \mathrm{mg} \cdot \mathrm{g}^{-1}\right)$ under outdoor conditions, produces only about $6.6 \mathrm{mg} \cdot \mathrm{L}^{-1}$ of secondary carotenoids. Hereupon, Chlorococcum microalgae could be a potential source for secondary carotenoids (including astaxanthin) in outdoor culture systems [52-54], should carotenogenic conditions be used $[50,52,55]$. For example, higher temperatures (around $35^{\circ} \mathrm{C}$ ) and more acidic $\mathrm{pH}$ could be favorable for astaxanthin production, although not for biomass production [48,52].

Undoubtedly, novel natural sources for carotenoids might be important since its demand is increasing, with expected values over $4 \%$ by 2024 in the carotenoids market size [3,10]. As a result, C. amblystomatis could be meet this demand for natural pigments due to its valuable content in chlorophyll and lutein even in non-inductive conditions.

\section{Conclusions}

A novel microalgal strain isolated at the Allmicroalgae production unit displayed promising growth performance and relevant biochemical composition at pilot and industrial scales. This strain is a free-living isolate of microalgae previously classified as Oophila amblystomatis (Clade A), which was renamed as C. amblystomatis in the present work. This strain showed significant potential for feed and food applications due to its high content of protein and PUFAs, which might also explain their importance as an egg symbiont of amphibians. Therefore, C. amblystomatis biomass could represent a promising, environmentally friendly alternative to the current food and feed consumers. Chlorophylls and lutein were also detected at valuable concentrations, adding value to the biomass produced, since they can be used as a natural food colorant and with promising applications in the nutraceutical and pharmaceutical industries.

Supplementary Materials: The following are available online at http://www.mdpi.com/2076-3417/10/9/3040/s1, Figure S1: HPLC chromatogram with peak area (mAU) and retention times (min) of neoxanthin (1), violaxanthin (2), lutein (3) and $\beta$-carotene (4) at $450 \mathrm{~nm}$. Figure S2: Calibration curve of peak area (mAU.min) versus neoxanthin concentration $\left(\mu \mathrm{g} \cdot \mathrm{mL}^{-1}\right)$, Figure S3: Calibration curve of peak area (mAU.min) versus violaxanthin concentration $\left(\mu \mathrm{g} \cdot \mathrm{mL}^{-1}\right)$. Figure S4: Calibration curve of peak area $(\mathrm{mAU} \cdot \mathrm{min})$ versus lutein concentration $\left(\mu \mathrm{g} \cdot \mathrm{mL}^{-1}\right)$. Figure S5: Calibration curve of peak area (mAU.min) versus $\beta$-carotene concentration $\left(\mu \mathrm{g} \cdot \mathrm{mL}^{-1}\right)$.

Author Contributions: Conceptualization: N.C., H.P., J.T.S., J.V., L.P., and J.S.; methodology: N.C., H.P., T.S., M.S., C.B.S., L.M.S.; validation: N.C., H.P., J.T.S., M.C., J.V., L.P. and J.S.; investigation: N.C., H.P., J.T.S., T.S., M.S., C.B.S., L.M.S., M.C., J.V., L.P., J.S.; writing—original draft preparation: N.C., H.P., M.S., C.B.S., L.M.S., M.C., J.V., L.P., J.S.; writing-review and editing: N.C., H.P., J.T.S., T.S., M.S., C.B.S., L.M.S., M.C., J.V., L.P., J.S.; supervision: J.V., 
L.P. and J.S.; funding acquisition: J.V., L.P. and J.S. All authors have read and agreed to the published version of the manuscript.

Funding: This research was funded by the Portuguese national budget P2020 in the scope of the project no. 023310 - ALGACO2: "Cultivo industrial de microalgas como tecnologia verde para captura de $\mathrm{CO}_{2}$ atmosférico". This study received Portuguese national funds from FCT - Foundation for Science and Technology through project UIDB/04326/2020, and from the operational programmes CRESC Algarve 2020 and COMPETE 2020 through projects EMBRC.PT ALG-01-0145-FEDER-022121 and BIODATA.PT ALG-01-0145-FEDER-022231 and support of Foundation for Science and Technology (FCT), within the scope of the project UIDB/04292/2020 - MARE - Marine and Environmental Sciences Centre.

Acknowledgments: The authors would like to acknowledge all members of Allmicroalgae Natural Products S.A. for the kind support and help throughout this work.

Conflicts of Interest: The authors declare no conflict of interest.

\section{References}

1. Guschina, I.A.; Harwood, J.L. Lipids and lipid metabolism in eukaryotic algae. Prog. Lipid Res. 2006, 45, 160-186. [CrossRef] [PubMed]

2. Guedes, A.C.; Amaro, H.; Malcata, F.X. Microalgae as sources of high added-value compounds-a brief review of recent work. Biotechnol. Prog. 2011, 27, 597-613. [CrossRef] [PubMed]

3. Spolaore, P.; Joannis-Cassan, C.; Duran, E.; Isambert, A. Commercial applications of microalgae. J. Biosci. Bioeng. 2006, 101, 87-96. [CrossRef]

4. Guedes, A.C.; Malcata, F.X. Nutritional Value and Uses of Microalgae in Aquaculture. Aquaculture $2012,390$. [CrossRef]

5. Gouveia, L.; Moura, P.; Reis, A.; Oliveira, C.; Gírio, F. Microalgae for Biofuels: The Portuguese Experience. 2015. Available online: http://www.lneg.pt/iedt/projectos/392/ (accessed on 14 January 2020).

6. Borowitzka, M.A.; Moheimani, N.R. Sustainable biofuels from algae. Mitig. Adapt. Strat. Glob. Chang. 2010, 18, 13-25. [CrossRef]

7. Pandey, A.; Lee, D.J.; Chisti, Y.; Soccol, C.R. Biofuels from Algae; Elsevier Inc.: Oxford, UK, 2013. [CrossRef]

8. Chew, K.W.; Yap, J.Y.; Show, P.L.; Suan, N.H.; Juan, J.C.; Ling, T.C.; Lee, D.S.; Chang, J.-S. Microalgae biorefinery: High value products perspectives. Bioresour. Technol. 2017, 229, 53-62. [CrossRef]

9. Ejike, C.E.; Collins, S.A.; Balasuriya, N.; Swanson, A.K.; Mason, B.; Udenigwe, C.C. Prospects of microalgae proteins in producing peptide-based functional foods for promoting cardiovascular health. Trends Food Sci. Technol. 2017, 59, 30-36. [CrossRef]

10. Pereira, H.; Silva, J.; Santos, T.; Gangadhar, K.N.; Raposo, A.; Nunes, C.; Coimbra, M.A.; Gouveia, L.; Barreira, L.; Varela, J. Nutritional Potential and Toxicological Evaluation of Tetraselmis sp. CTP4 Microalgal Biomass Produced in Industrial Photobioreactors. Molecules 2019, 24, 3192. [CrossRef]

11. Dionisi, H.; Lozada, M.; Olivera, N.L. Bioprospection of marine microorganisms: Biotechnological applications and methods. Rev. Argent. Microbiol. 2012, 44.

12. Pereira, H.; Páramo, J.; Silva, J.; Marqués, A.; Barros, A.; Maurício, D.; Santos, T.; Schulze, P.S.; Barros, R.; Gouveia, L.; et al. Scale-up and large-scale production of Tetraselmis sp. CTP4 (Chlorophyta) for $\mathrm{CO}_{2}$ mitigation: From an agar plate to 100- $\mathrm{m}^{3}$ industrial photobioreactors. Sci. Rep. 2018, 8, 5112. [CrossRef] [PubMed]

13. Pandey, M.K.; Dasgupta, C.N.; Mishra, S.; Srivastava, M.; Gupta, V.K.; Suseela, M.R.; Ramteke, P.W. Bioprospecting microalgae from natural algal bloom for sustainable biomass and biodiesel production. Appl. Microbiol. Biotechnol. 2019, 103, 5447-5458. [CrossRef] [PubMed]

14. Parvin, M.; Zannat, M.N.; Habib, M.A.B. Two Important Techniques for Isolation of Microalgae. 2007, Volume 20. Available online: www.asianfisheriessociety.org (accessed on 14 January 2020).

15. Pereira, H.; Barreira, L.; Mozes, A.; Florindo, C.; Polo, C.; Vizetto-Duarte, C.; Custódio, L.; Varela, J. Microplate-based high throughput screening procedure for the isolation of lipid-rich marine microalgae. Biotechnol. Biofuels 2011, 4, 61. [CrossRef] [PubMed]

16. Nylander, J.A.A. MrModeltest v2. Progr Distrib by author. 2004. Available online: https://github.com/ nylander/MrModeltest2 (accessed on 7 February 2020).

17. Swofford, D.L. PAUP*. Phylogenetic Analysis Using Parsimony (*and Other Methods). 2003. Available online: http://paup.csit.fsu.edu/ (accessed on 9 February 2020). 
18. Stamatakis, A. RAxML-VI-HPC: Maximum likelihood-based phylogenetic analyses with thousands of taxa and mixed models. Bioinformatics 2006, 22, 2688-2690. [CrossRef] [PubMed]

19. Huelsenbeck, J.P.; Ronquist, F. MRBAYES: Bayesian Inference of Phylogenetic Trees. Yang and Rannala. 2001, Volume 17. Available online: http://brahms.biology.rochester.edu/software.html (accessed on 9 February 2020).

20. Ronquist, F.; Huelsenbeck, J.P. MrBayes 3: Bayesian phylogenetic inference under mixed models. Bioinformatics 2003, 19, 1572-1574. [CrossRef]

21. Rambaut, A.; Suchard, M.A.; Xie, D.; Drummond, A.J. TRACER v1.6. 2014. Available online: http: //beast.bio.ed.ac.uk/Tracer (accessed on 7 February 2020).

22. Rambaut, A. FigTree v1.4.2. 2009. Available online: http://tree.bio.ed.ac.uk/software/figtree (accessed on 7 February 2020).

23. Callejón-Ferre, Á.J.; Martí, B.V.; López-Martínez, J.; Manzano-Agugliaro, F. Greenhouse crop residues: Energy potential and models for the prediction of their higher heating value. Renew. Sustain. Energy Rev. 2011, 15, 948-955. [CrossRef]

24. Nunez, M.; Quigg, A. Changes in growth and composition of the marine microalgae Phaeodactylum tricornutum and Nannochloropsis salina in response to changing sodium bicarbonate concentrations. J. Appl. Phycol. 2016, 28, 2123-2138. [CrossRef]

25. Bligh, E.G.; Dyer, W.J. A Rapid Method of Total Lipid Extraction and Purification. Can. J. Biochem. Physiol. 1959, 37, 911-917. [CrossRef]

26. Lepage, G.; Roy, C.C. Improved recovery of fatty acid through direct transesterification without prior extraction or purification. J. Lipid Res. 1984, 25.

27. Couso, I.; Vila, M.; Vigara, J.; Cordero, B.F.; Vargas, M.Á.; Rodríguez, H.; León, R.; Lianez, I.C. Synthesis of carotenoids and regulation of the carotenoid biosynthesis pathway in response to high light stress in the unicellular microalga Chlamydomonas reinhardtii. Eur. J. Phycol. 2012, 47, 223-232. [CrossRef]

28. Bold, H.C.; Parker, B.C. Some supplementary attributes in the classification of chlorococcum species. Arch. Microbiol. 1962, 42, 267-288. [CrossRef]

29. Watanabe, S.; Lewis, L. Phylogenetic interpretation of light and electron microscopic features of selected members of the phylogroup Moewusinia (Chlorophyceae), with new generic taxonomy. Phycologia 2017, 56, 329-353. [CrossRef]

30. Bold, H.C. Life History and Cell Structure of Chlorococcum infusionum. Bull. Torrey Bot. Club 1930, 57, 577. [CrossRef]

31. Temraleeva, A.D.; Moslalenko, S.V. Application of Morphological and Molecular Systematics for Identification of Green Microalgae of the Genus Chlorococcum and Some Closely Related Taxa. Microbiology 2019, 88, 27-38. [CrossRef]

32. Nema, M.; Hanson, M.L.; Müller, K.M. Phylogeny of the egg-loving green alga Oophila amblystomatis (Chlamydomonadales) and its response to the herbicides atrazine and 2,4-D. Symbiosis 2018, 77, $23-39$. [CrossRef]

33. Lin, Y.; Bishop, C.D. Identification of free-living Oophila amblystomatis (Chlorophyceae) from Yellow Spotted Salamander and Wood Frog breeding habitat. Phycologia 2015, 54, 183-191. [CrossRef]

34. Cabanelas, I.T.D.; Slegers, P.M.; Böpple, H.; Kleinegris, D.M.M.; Wijffels, R.H.; Barbosa, M. Outdoor performance of Chlorococcum littorale at different locations. Algal Res. 2017, 27, 55-64. [CrossRef]

35. Quelhas, P.M.; Trovão, M.; Silva, J.T.; Machado, A.; Dos Santos, M.; Pereira, H.; Varela, J.; Simões, M.; Silva, J.L. Industrial production of Phaeodactylum tricornutum for $\mathrm{CO}_{2}$ mitigation: Biomass productivity and photosynthetic efficiency using photobioreactors of different volumes. J. Appl. Phycol. 2019, 31, 2187-2196. [CrossRef]

36. Chen, C.-Y.; Zhao, X.-Q.; Yen, H.-W.; Ho, S.-H.; Cheng, C.-L.; Lee, D.S.; Bai, F.-W.; Chang, J.-S. Microalgae-based carbohydrates for biofuel production. Biochem. Eng. J. 2013, 78, 1-10. [CrossRef]

37. Shankar, M.; Chhotaray, P.; Agrawal, A.; Gardas, R.L.; Tamilarasan, K.; Rajesh, M. Protic ionic liquid-assisted cell disruption and lipid extraction from fresh water Chlorella and Chlorococcum microalgae. Algal Res. 2017, 25, 228-236. [CrossRef]

38. Del Río, E.; García-Gómez, E.; Moreno, J.; Guerrero, M.; Garcia-González, M.; Sanchez, E.D.R. Microalgae for oil. Assessment of fatty acid productivity in continuous culture by two high-yield strains, Chlorococcum oleofaciens and Pseudokirchneriella subcapitata. Algal Res. 2017, 23, 37-42. [CrossRef] 
39. Sahu, A.; Pancha, I.; Jain, D.; Paliwal, C.; Ghosh, T.; Patidar, S.; Bhattacharya, S.; Mishra, S. Fatty acids as biomarkers of microalgae. Phytochemistry 2013, 89, 53-58. [CrossRef] [PubMed]

40. Feng, P.; Deng, Z.; Hu, Z.; Wang, Z.; Fan, L. Characterization of Chlorococcum pamirum as a potential biodiesel feedstock. Bioresour. Technol. 2014, 162, 115-122. [CrossRef] [PubMed]

41. Schmitz, G.; Ecker, J. The opposing effects of n-3 and n-6 fatty acids. Prog. Lipid Res. 2008, 47, 147-155. [CrossRef] [PubMed]

42. Kumari, P.; Kumar, M.; Gupta, V.; Reddy, C.; Jha, B. Tropical marine macroalgae as potential sources of nutritionally important PUFAs. Food Chem. 2010, 120, 749-757. [CrossRef]

43. Connor, W.E. Importance of n-3 fatty acids in health and disease. Am. J. Clin. Nutr. 2000, 71, 171S-175S. [CrossRef]

44. Mostafa, S. Microalgal Biotechnology: Prospects and Applications. Plant Sci. 2012. [CrossRef]

45. Harun, R.; Singh, M.; Forde, G.M.; Danquah, M.K. Bioprocess engineering of microalgae to produce a variety of consumer products. Renew. Sustain. Energy Rev. 2010, 14, 1037-1047. [CrossRef]

46. Pereira, H.; Barreira, L.; Figueiredo, F.; Custódio, L.; Vizetto-Duarte, C.; Polo, C.; Rešek, E.; Engelen, A.; Varela, J. Polyunsaturated Fatty Acids of Marine Macroalgae: Potential for Nutritional and Pharmaceutical Applications. Mar. Drugs 2012, 10, 1920-1935. [CrossRef]

47. Van Ginneken, V.J.; Helsper, J.P.F.G.; De Visser, W.; Van Keulen, H.; A Brandenburg, W. Polyunsaturated fatty acids in various macroalgal species from north Atlantic and tropical seas. Lipids Health Dis. 2011, 10, 104. [CrossRef]

48. Liu, B.-H.; Lee, Y.-K. Secondary carotenoids formation by the green alga Chlorococcum sp. J. Appl. Phycol. 2000, 12, 301-307. [CrossRef]

49. Balder, H.F.; Vogel, J.; Jansen, M.C.; Weijenberg, M.P.; Westenbrink, S.; Van Der Meer, R.; Goldbohm, R.A.; Brandt, P.A.V.D. Heme and Chlorophyll Intake and Risk of Colorectal Cancer in the Netherlands Cohort Study. Cancer Epidemiol. Biomark. Prev. 2006, 15, 717-725. [CrossRef] [PubMed]

50. Sevilla, J.M.F.; Acién, F.G.; Grima, E.M. Biotechnological production of lutein and its applications. Appl. Microbiol. Biotechnol. 2010, 86, 27-40. [CrossRef] [PubMed]

51. Tinoco, N.A.B.; Teixeira, C.M.L.L.; De Rezende, C.M. The Genus Dunaliella: Biotechnology and Applications. Rev. Virtual Química 2015, 7, 1421-1440. [CrossRef]

52. Zhang, D.H.; Ng, Y.K.; Phang, S.M. Composition and accumulation of secondary carotenoids in Chlorococcum sp. J. Appl. Phycol. 1997, 9, 147-155. [CrossRef]

53. Lorenz, R.; Cysewski, G.R. Commercial potential for Haematococcus microalgae as a natural source of astaxanthin. Trends Biotechnol. 2000, 18, 160-167. [CrossRef]

54. Yuan, J.-P.; Chen, F.; Liu, X.; Li, X.-Z. Carotenoid composition in the green microalga Chlorococcum. Food Chem. 2002, 76, 319-325. [CrossRef]

55. Zhang, D.H.; Lee, Y.K. Enhanced accumulation of secondary carotenoids in a mutant of the green alga, Chlorococcum sp. J. Appl. Phycol. 1997, 9, 459-463. [CrossRef]

(C) 2020 by the authors. Licensee MDPI, Basel, Switzerland. This article is an open access article distributed under the terms and conditions of the Creative Commons Attribution (CC BY) license (http://creativecommons.org/licenses/by/4.0/). 